\title{
Effect of Pre-Slaughter Antacid Supplementation of Drinking Water on Carcass Yield and Meat Quality of Broiler Chickens
}

\author{
Siriporn Namted ${ }^{1}$, Khwanchai Srisuwan ${ }^{2}$, Chaiyapoom Bunchasak ${ }^{2}$, and Choawit Rakangthong ${ }^{2 *}$ \\ ${ }^{I}$ Department of Agriculture, Faculty of Agriculture Technology, Valaya Alongkron Rajabhat University \\ under the Royal Patronage Pathumthani, Pathumthani 13180, Thailand \\ ${ }^{2}$ Department of Animal Science, Faculty of Agriculture, Kasetsart University, Bangkok 10900, Thailand \\ *Corresponding author's Email: choawit@hotmail.com; ORCID: 0000-0002-7999-7549
}

Received: 25 Dec. 2020

Accepted: 04 Feb. 2021

\begin{abstract}
Antacid is a mixture of sodium bicarbonate, bicarbonate, and citric acid, which can neutralize stomach acidity and may stabilize the $\mathrm{pH}$ of post-mortem carcass and meat. Therefore, the present study aimed to investigate the carcass and meat quality of broiler chickens by supplementing the antacid in drinking water. A total of 48 male broiler chickens (Ross 308) were divided into two groups that the first group was the control group (did not receive antacid supplementation in the drinking water) and the second group was supplemented with antacid in drinking water $(0.10 \%)$ for three days pre-slaughter. It was found that the antacid supplementation increased the percentage of breast meat, while carcass yield, and thigh, drumstick, and wing were not significantly affected. The $\mathrm{pH}$ of breast meat 45 minutes and the drip loss at 24 hours post-slaughter was significantly higher. The shear-force of breast meat was reduced $(\mathrm{P}<0.05)$ by antacid supplementation. For the color of the breast meat, there were no significant differences in lightness $\left(\mathrm{L}^{*}\right)$, redness $\left(\mathrm{a}^{*}\right)$, and yellowness $\left(\mathrm{b}^{*}\right)$ between the two groups, but the total difference in the color of meat was slightly increased. It can be concluded that supplementing the drinking water with an antacid for three days before slaughter improves the carcass and meat quality of broiler chickens by maintaining the $\mathrm{pH}$ and water holding capacity of the meat.
\end{abstract}

Key words: Antacid, Broiler chickens, Carcass yield, Meat quality.

\section{INTRODUCTION}

Meat quality is influenced by the interaction between the genotype and the environment, particularly the stresses undergone before slaughter (Ali et al., 2008). Under stress, it is known that self-oxidative peroxidation increases free radicals, oxygen-reactive species, resulting in destabilization of the cell wall (Puthpongsiriporn et al., 2001). Excessive levels of free radicals enhance lipid peroxidation and changes in meat organoleptic characteristics (Fellenberg and Speisky, 2006). Furthermore, muscle from the broiler chickens stressed pre-slaughter by transportation or high temperatures normally becomes pale, soft, moist, or exudative after a normal 18-24 hours chilling period. Due to rapid $\mathrm{pH}$ decline and protein denaturation, this often results in lower possessing yields, increased cooking losses, and reduced juiciness (Ali et al., 2008).

Under heat stress, hyperventilation normally decreases blood carbon dioxide, thereby inducing respiratory alkalosis (increased blood $\mathrm{pH}$ ) in chickens
(Borges et al., 2007). Glycolysis and creatine kinase activity are stimulated, resulting in more pyruvate conversion to lactate (anaerobic metabolism), and inducing acidosis in meat under heat stress (Song and King, 2019). Sodium bicarbonate is an absorbable systemic buffer that supplies sodium and bicarbonate to the body; dietary sodium bicarbonate supplementation to laying hens improves body acid-base balance and eggshell quality (Jiang et al., 2015). In broiler chickens, under heat stress, supplementation of sodium bicarbonate in the drinking water or feed could reduce mortality rate (Mushtaq et al., 2007), and improve growth performance (Mushtaq et al., 2014). Furthermore, using sodium bicarbonate $(5.49 \mathrm{~g} / \mathrm{kg}$ diet $)$ resulted in better growth and carcass performance in broiler chickens compared to other dietary electrolyte balances (Mushtaq et al., 2014).

An antacid is a mixture of sodium bicarbonate, bicarbonate, and citric acid, which can neutralize stomach acidity in humans. Respiratory alkalosis increases the excretion of citric acid, while acidosis decreases the 
excretion of citrate (Jiang et al., 2015). For example, ingestion of an alkali load (citrate mixture and sodium bicarbonate) results in an increase in urinary citrate excretion (Xue et al., 2020). The reaction between sodium bicarbonate and citric acid forms carbon dioxide (quickly absorbed) and sodium citrate (high buffering capacity). Since meat quality is directly related to the metabolic acidosis that converts more pyruvate to lactate (anaerobic metabolism), an increase of $\mathrm{pH}$ in muscle cells can improve the meat quality. However, the effects of therapeutic antacid chemicals on post-mortem carcasses and meat quality have not been reported. Therefore, the current study was conducted to evaluate the effect of supplementing drinking water with antacid on carcass yield and meat quality of broiler chickens ( 3 days preslaughter).

\section{MATERIALS AND METHODS}

\section{Ethical approval}

The experimental animals were kept, maintained, treated, and handled in accordance with accepted standards for the humane treatment of animals under license number U1-07385-2561.

\section{Animals and management}

A total of 48 male broiler chickens (Ross 308) were kept in an evaporative cooling system from day 1 to day 35 of age, and maintained, treated, and handled under accepted standards for the humane treatment of animals (according to animal welfare). Management and vaccination were provided according to commercial practices. Water and feed were offered ad libitum. At 32 days of age, the chickens were divided into two experimental groups of 24 . The basal diet was formulated to contain $23 \% \mathrm{CP}$ and $3,000 \mathrm{ME} \mathrm{kcal} / \mathrm{kg}$ for age 1 to 10 days, $21.50 \% \mathrm{CP}$ and 3,100 ME kcal/kg for age 11 to 24 days, and $19.50 \% \mathrm{CP}$ and 3,200 ME kcal $/ \mathrm{kg}$ for age 25 to 35 days). All nutrient requirements were formulated according to the recommendations for the strain (Table 1).

\section{Antacid supplementation in the drinking water}

During 32-35 days of age, the drinking water was supplemented with antacid in order to evaluate the carcass and meat quality. The experimental groups were assigned to the control group in which the chickens received no supplementation in the drinking water and the antacid group where Citric acid (43.33\%), sodium bicarbonate $(46.67 \%)$, and bicarbonate $(10.00 \%)$ were added to the drinking water at $0.10 \%$.

Table 1. Composition and nutritional content of the experimental diets

\begin{tabular}{|c|c|c|c|}
\hline Item & Age 1 to 10 days & Age 11 to 24 days & Age 25 to 35 days \\
\hline Corn & 49.11 & 51.92 & 56.57 \\
\hline Soybean meal (48\% Crude protein) & 40.73 & 37.30 & 32.27 \\
\hline Rice bran oil & 4.95 & 5.99 & 6.71 \\
\hline Monodicalciumphosphate (22\% Phosphorus) & 1.54 & 1.36 & 1.22 \\
\hline Limestone & 1.43 & 1.30 & 1.19 \\
\hline Salt & 0.58 & 0.48 & 0.29 \\
\hline Sodium bicarbonate & - & 0.15 & 0.30 \\
\hline DL-Methionine & 0.34 & 0.28 & 0.26 \\
\hline L-Lysine & 0.19 & 0.12 & 0.12 \\
\hline L-Threonine & 0.10 & 0.07 & 0.04 \\
\hline Vitamin and mineral premix & 0.24 & 0.24 & 0.24 \\
\hline Choline chloride $(60 \%)$ & 0.08 & 0.08 & 0.08 \\
\hline Antioxidant and toxin binder & 0.16 & 0.16 & 0.16 \\
\hline Anticoccidial & 0.05 & 0.05 & 0.05 \\
\hline corncob & 0.50 & 0.50 & 0.50 \\
\hline Total & 100.00 & 100.00 & 100.00 \\
\hline \multicolumn{4}{|l|}{ Nutrients by calculation } \\
\hline Metabolisable energy $(\mathrm{Kcal} / \mathrm{Kg})$ & 3000.00 & 3100.00 & 3200.00 \\
\hline Crude protein $(\%)$ & 23.00 & 21.50 & 19.50 \\
\hline Fiber $(\%)$ & 3.57 & 3.43 & 3.24 \\
\hline Fat $(\%)$ & 7.32 & 8.40 & 9.21 \\
\hline Methionine (\%) & 0.68 & 0.61 & 0.56 \\
\hline Methionine+cystine (\%) & 1.08 & 0.99 & 0.91 \\
\hline Lysine $(\%)$ & 1.44 & 1.29 & 1.16 \\
\hline Threonine (\%) & 0.97 & 0.88 & 0.78 \\
\hline Valine & 1.11 & 1.04 & 0.95 \\
\hline Calcium (\%) & 0.96 & 0.87 & 0.79 \\
\hline Total phosphorus (\%) & 0.72 & 0.67 & 0.62 \\
\hline Available phosphorus (\%) & 0.48 & 0.44 & 0.39 \\
\hline Sodium $(\%)$ & 0.23 & 0.23 & 0.20 \\
\hline
\end{tabular}




\section{Carcass and meat quality}

At 35 days of age, the feed was removed for 12 hours before processing. Twenty-four broilers from each group were killed using $\mathrm{CO}_{2}$ asphyxiation in an atmosphere of less than $2 \%$ oxygen (air displaced by $\mathrm{CO}_{2}$ ) for 1.5-2.0 minutes. The breast meat, thigh, wing, and drumstick of all chickens were collected, weighed, and calculated as a percentage of the live body weight. Meat quality measurements were carried out on pectoralis major. The $\mathrm{pH}$ values at 0 and 45 minutes were measured using a $\mathrm{pH}$ measuring instrument (model HI 99163; Hanna Instruments, Wilmington, MA, USA, (Glamoclija et al., 2015). The breast muscles were refrigerated overnight at $4^{\circ} \mathrm{C}$, and then kept at room temperature before cooking. For cooking loss, the breast muscle from each broiler chicken was cooked to an internal temperature of $70^{\circ} \mathrm{C}$ measured using a digital thermostated water bath (HH-4, Jiangbo Instrument, Jiangsu, China), then cooled to the room temperature, and then weighed. The Warner-Bratzler shear force of the breast meat was determined using an Instron universal tensile tester (Instron model 4411, Instron Corp., Canton, MA, Jiang et al., 2007).

Meat color was measured 45 minutes post-mortem using a chromameter (CR-410, Minolta Co. Ltd, Suita-shi, Osaka, Japan) to measure the CIE LAB values (L* measures relative lightness, $\mathrm{a}^{*}$ measures relative redness, and $b^{*}$ measures relative yellowness). Readings were taken at the surface of the sample representing the whole surface of the muscle (Jiang et al., 2007). Deltas for $\mathrm{L}^{*}$ $\left(\Delta \mathrm{L}^{*}\right), \mathrm{a}^{*}\left(\Delta \mathrm{a}^{*}\right)$, and $\mathrm{b}^{*}\left(\Delta \mathrm{b}^{*}\right)$ may be positive $(+)$ or negative (-). The total difference, Delta $\mathrm{E}\left(\Delta \mathrm{E}^{*}\right)$, however, is always positive (AMSA, 2012). The total difference, Delta $\mathrm{E}\left(\Delta \mathrm{E}^{*}\right)$, however, is always positive (AMSA, 2012).

$\Delta \mathrm{L}^{*}\left(\mathrm{~L}^{*}\right.$ sample $-\mathrm{L}^{*}$ standard): difference in lightness and darkness (+ : lighter, $-:$ darker $) ; \Delta \mathrm{a}^{*}\left(\mathrm{a}^{*}\right.$ sample $-\mathrm{a}^{*}$ standard): difference in red and green $(+:$ redder, $-=$ greener); $\Delta b^{*}\left(b^{*}\right.$ sample $-b^{*}$ standard $):$ difference in yellow and blue $(+:$ yellower, $-=$ bluer $)$.

$\Delta \mathrm{E}^{*}: \sqrt{\left(L_{2}^{*}-L_{1}^{*}\right)^{2}+\left(a_{2}^{*}-a_{1}^{*}\right)^{2}+\left(b_{2}^{*}-b_{1}^{*}\right)^{2}}$

\section{Statistical analysis}

A t-test was used to compare measured values obtained from the two independent groups of the carcass and meat quality of the broiler chickens. Statements of statistical significance were based on $p<0.05$.

\section{RESULTS AND DISCUSSION}

\section{Carcass yield}

The effects of supplemented drinking water with antacid on the carcass yield of broiler chickens are presented in Table 2. The weight of breast meat increased significantly with supplemental antacid in the drinking water $(p=0.02)$, while there were no significant effects of the supplementation on carcass yield, carcass percentage, or thigh, drumstick, and wing weight.

Dietary sodium bicarbonate has been reported to improve the body weight, carcass yield, breast meat yield, and abdominal fat of broiler chickens (Yasoob and Tauqir, 2017) although the addition of sodium bicarbonate to the drinking water alone during pre-slaughter did not influence the carcass yield or meat quality of broiler chickens (Petrolli et al., 2016). In terms of mixed solutions, however, Ma et al. (2015) found that electrolyte solutions (containing sugar, sodium chloride, potassium chloride, sodium bicarbonate, and citric acid) significantly increased the body weight of stressed pigs by $15.64 \%$. Moreover, supplementing drinking water using commercial electrolyte packs at $0.10 \%$ for 3 days prior to slaughter also improved weight gain and percentage of carcass water uptake (no significant difference) of turkeys, broiler chickens, and pigs during the final 25 days (Ma et al., 2015). Accordingly, the current study showed that adding antacid (a mixture of sodium bicarbonate, bicarbonate, and citric acid) to drinking water during the three days pre-slaughter increased the breast meat weight of the broiler chickens. This indicates that antacid does not neutralize the acidity only in the stomach, but it improves the acid-base balance at the cellular level. Consequently, it maintains cellular metabolism in the breast muscle of the chickens.

Table 2. Effect of antacid supplementation in drinking water on carcass quantity of broiler chickens

\begin{tabular}{|c|c|c|c|c|}
\hline Item & Control group & Antacid group & $p$ value & SEM \\
\hline Carcass yield (g) & $1,890.04 \pm 71.94$ & $1,887.42 \pm 46.45$ & 0.91 & 12.09 \\
\hline Breast (\%) & $21.69 \pm 0.73$ & $22.99 \pm 1.66^{*}$ & 0.02 & 0.29 \\
\hline Thigh (\%) & $13.90 \pm 1.08$ & $13.75 \pm 1.27$ & 0.76 & 0.23 \\
\hline Wing $(\%)$ & $8.07 \pm 0.25$ & $7.84 \pm 0.27$ & 0.07 & 0.05 \\
\hline
\end{tabular}

Values presented as mean \pm SD. ${ }^{*}$ Means within a row with different letters indicate a significant difference $(\mathrm{P}<0.05)$. SEM: Standard Error of Measurement 


\section{Meat quality}

The effects of adding antacid to the drinking water on the quality of breast meat of the broiler chickens are presented in table 3 . There was no significant difference among the $\mathrm{pH}$ of the meat of the experimental groups at 0 minutes, while the $\mathrm{pH}$ of the antacid group was significantly higher than that of the control group at 45 minutes $(\mathrm{P}<0.05)$. Adding antacid to the drinking water decreased the drip loss of the meat at 24 hours $(\mathrm{P}<0.05)$ and 48 hours $(p=0.06)$. Moreover, the shear force value was significantly reduced by supplementation of the drinking water $(\mathrm{p}<0.01)$ although the cooking loss was not affected. For the color of the breast meat, there were no significant differences between the two groups for the $L^{*} a^{*}$ and $b *$ values $(p>0.05)$ while the total difference in color was slightly increased.

Since the aerobic metabolism in muscle changes to anaerobic metabolism after the oxygen supply is stopped, the rate of pyruvate conversion to lactate is increased (Zhang et al., 2009). Rapid post-mortem glycolysis while carcass temperature is still high results in a rapid drop in
$\mathrm{pH}$, protein denaturation, pale meat color, reduced water holding capacity, and poor texture (Song and King, 2019). Bicarbonate is a blood buffer that maintains both extracellular and intracellular $\mathrm{pH}$, and sodium bicarbonate supplementation increases blood bicarbonate concentrations, resulting in blood alkalosis (Lancha et al., 2015). Several investigators have reported that supplementing with sodium bicarbonate results in high $\mathrm{pH}$ in chicken meat (Woelfel and Sams, 2001) and pork (Wynveen et al., 2001). Therefore, a high $\mathrm{pH}$ in meat reduces the percentage of drip loss by an improvement in the water holding capacity (Fischer, 2007). The water holding capacity of meat is minimal when the $\mathrm{pH}$ is close to the isoelectric point of myofibrillar proteins (about 5.25.3 in poultry meat) while the ionic strength could be steadily increased by adjusting the $\mathrm{PH}$, thus it leads to an increase in the water holding capacity of meat products (Barbut, 2002; Petracci and Cavani, 2012). Therefore, it is clear that supplementing drinking water with antacid will improve the water holding capacity of meat by maintaining the $\mathrm{PH}$.

Table 3. Effect of antacid supplementation in drinking water on meat quality of broiler chickens

\begin{tabular}{lcccc}
\hline Item & Control group & Antacid group & p value & SEM \\
\hline $\mathrm{pH}_{0}$ & $7.17 \pm 0.20$ & $7.26 \pm 0.21$ & 0.34 & 0.04 \\
$\mathrm{pH}_{45}$ & $6.63 \pm 0.22$ & $6.84 \pm 0.22^{*}$ & 0.03 & 0.05 \\
Drip loss24 hr. (\%) & $2.63 \pm 0.61$ & $2.16 \pm 0.42^{*}$ & 0.03 & 0.11 \\
Drip loss48 hr. (\%) & $3.50 \pm 0.79$ & $2.92 \pm 0.68$ & 0.06 & 0.15 \\
Cooking loss (\%) & $26.52 \pm 3.26$ & $26.60 \pm 2.89$ & 0.94 & 0.61 \\
Shear force (N) & $43.47 \pm 5.01$ & $29.92 \pm 5.29^{* *}$ & $<0.01$ & 2.65 \\
$\mathrm{~L}^{*}$ & $42.70 \pm 2.17$ & $41.64 \pm 3.99$ & 0.35 & 0.65 \\
$\mathrm{a}^{*}$ & $1.77 \pm 0.74$ & $2.15 \pm 0.99$ & 0.29 & 0.18 \\
$\mathrm{~b}^{*}$ & $13.15 \pm 0.76$ & $13.16 \pm 1.17$ & 0.97 & 0.19 \\
$\Delta \mathrm{L}^{*}$ & 0 & -1.06 & - & - \\
$\Delta \mathrm{a}{ }^{*}$ & 0 & 0.38 & - & - \\
$\Delta \mathrm{b}^{*}$ & 0 & 0.01 & - & - \\
Total color difference between the control & 0 & 1.12 & - & - \\
group $\left(\Delta \mathrm{E}^{*}\right)$ & & & & - \\
\hline Val pres & & 0.35 &
\end{tabular}

Values presented as mean \pm SD. ${ }^{*} \mathrm{P}<0.05 ;{ }^{* *} \mathrm{P}<0.01, \mathrm{~L}^{*}$ : Lightness, $\mathrm{a}^{*}$ : Redness, $\mathrm{b}^{*}$ : Yellowness, SEM: Standard Error of Measurement

An increase in the $\mathrm{pH}$ of meat at 45 minutes by supplementing the antacid in drinking water may be due to the high buffering capacity and ionic strength of bicarbonate and sodium citrate. the reason is that sodium bicarbonate reacted with citric acid to produce sodium citrate, which is dissociated from citrate anion (Stephens et al., 2008). Therefore, a reduction in $\mathrm{H}+$ and an elevation in bicarbonate in plasma resulting in an increase of the extracellular buffering capacity (Tugnoli et al., 2020). The increase in blood $\mathrm{pH}$ through sodium citrate supplementation induces more efflux of $\mathrm{H}+$ and lactate from the active muscles via monocarboxylate transporter (Requena et al., 2005). This implies that sodium citrate may provide a high buffering capacity to improve the acidbase balance in meat.

Moreover, the findings of the present study showed that the shear-force of the meat was reduced by antacid supplementation of the drinking water. There are reports 
indicating that sodium bicarbonate reduced the shear force and improved the yield of pork and poultry meat (Mudalal and Petracci, 2019). However, broiler chickens given $0.50 \%$ sodium bicarbonate from five to eight weeks of age had meat of higher shear force than those given a combination of $0.50 \%$ sodium bicarbonate and $0.50 \%$ potassium chloride (Hao and $\mathrm{Gu}, 2014$ ). It may be said that supplementing with antacid (electrolyte solution) may have more impact on the shear-force than sodium bicarbonate alone.

A rapid drop in $\mathrm{pH}$ may be associated with low redness, high lightness and high drip, and cooking losses in chickens' breast meat (Hao and $\mathrm{Gu}, 2014$ ). The use of bicarbonate to minimize the problem of pale, soft, and exudative meat has been reported in pork (Wynveen et al., 2001; Mudalal and Petracci, 2019) and poultry (Woelfel and Sams, 2001; Alvarado and Sams, 2003). However, a low incidence of Pale Soft Exudative (PSE) meat was presented in the current study (all $\mathrm{pH}$ values were above 5.8 and $\mathrm{L}^{*}$ values were below 52). This pigmentation/redness ratio was used to assess myoglobin oxidation, with high redness values indicating high myoglobin oxidation (Kim et al., 2010). Although the $\mathrm{L}^{*}$, $\mathrm{a}^{*}$, and $\mathrm{b}^{*}$ colors were not significantly affected, a slight increase in the total color difference in the antacid group may be due to the maintenance of the $\mathrm{pH}$ and water holding capacity.

\section{CONCLUSION}

Since the supplementation can maintain the $\mathrm{pH}$ and water holding capacity of the meat, it is concluded that the antacid (a mixture of sodium bicarbonate, bicarbonate, and citric acid) should be added to the drinking water for three days before slaughter to improve carcass (percentage of breast meat) and meat quality ( $\mathrm{pH}$ at 45 minutes, drip loss percentage at 24 and 48 hours and shear force) of broiler chickens.

\section{DECLARATIONS}

\section{Acknowledgments}

This work was facilitated by the department of animal science, faculty of agriculture, Kasetsart University, Thailand. The authors would like to thank the department of agriculture, faculty of agriculture technology, Valaya Alongkron Rajabhat University for all their supports.

\section{Authors' contribution}

Namted S and Rakangthong C developed the concept, analyzed data, and wrote the manuscript. Namted $\mathrm{S}$ and
Srisuwan $\mathrm{K}$ assisted in data collection while Bunchasak C designed the graphical abstract. All authors reviewed and confirmed the manuscript before submission.

\section{Competing interests}

The authors declare that they have no conflict of interest.

\section{REFERENCES}

Ali MS, Kang GH, and Joo ST (2008). A Review: Influences of preslaughter stress on poultry meat quality. Asian-Australasian Journal of Animal Sciences, 21: 912-916. DOI: https://www.doi.org/10.5713/ajas.2008.r.06

Alvarado CZ, and Sams AR (2003). Injection marination strategies for remediation of pale, exudative broiler breast meat. Poultry Science, 82: 1332-1336. DOI: https://www.doi.org/10.1093/ps/82.8.1332

(AMSA) American Meat Science Association (2012). Meat Color Measurement Guidelines. West Springfield Avenue, Suite 1202 Champaign, Illinois USA, pp. 45-50. Available at: http://www.meatscience.org

Barbut S (2002). Measuring sensory and functional properties. In: Poultry Products Processing: An Industry Guide. CRC Press, New York, NY, pp. 467-511. DOI: https://www.doi.org/10.1201/9781420031744

Borges SA, Fischer Da Silva AV, and Maiorka A (2007). Acid-base balance in broilers. World's Poultry Science Journal, 63: 73-81. DOI: https://www.doi.org/10.1017/S0043933907001286

Fellenberg A, and Speisky HC (2006). Antioxidants: Their effects on broiler oxidative stress and its meat oxidative stability. World's Poultry Science Journal, 62: 53-70. DOI: https://www.doi.org/10.1079/WPS200584

Fischer K (2007). Drip loss in pork: influencing factors and relation to further meat quality traits. Journal of Animal Breeding and Genetics, 124: 12-18. DOI: https://www.doi.org/10.1111/j.14390388.2007.00682.x

Song DJ, and King AJ (2019). Effects of heat stress on broiler meat quality. World's Poultry Science Journal, 71(4): 701-709. DOI: https://www.doi.org/10.1017/S0043933915002421

Glamoclija N, Starcevic M, Janjic J, Ivanovic J, Boskovica M, Djordjevic J, Admila Markovic R, and Baltic MZ (2015). The effect of breed line and age on measurements of $\mathrm{pH}$-value as meat quality parameter in breast muscles ( $m$. pectoralis major) of broiler chickens. Procedia Food Science, 5: 89-92. DOI: https://www.doi.org/10.1016/j.profoo.2015.09.023

Hao Y, and Gu XH (2014). Effects of heat shock protein 90 expression on pectoralis major oxidation in broiler sex posed to acute heat stress. Poultry Science, 93: 2709-2717. DOI: https://www.doi.org/10.3382/ps.2014-03993

Jiang MJ, Zhao JP, Jiao HC, Wang XJ, Zhang Q, and Lin H (2015). Dietary supplementation with sodium bicarbonate improves calcium absorption and eggshell quality of laying hens during peak production. British Poultry Science, 56: 740-747. DOI: https://www.doi.org/10.1080/00071668.2015.1113499

Jiang ZY, Jiang SQ, Lin YC, Xi PB, Yu DQ, and Wu TX (2007). Effects of soybean isoflavone on growth performance, meat quality, and 
antioxidation in male broilers. Poultry Science, 86: 1356-1362. DOI: https://www.doi.org/10.1093/ps/86.7.1356

Kim GD, Jeong JY, Hur SJ, Yang HS, Jeon JT, and Joo ST (2010). The Relationship between Meat Color (CIE L* and $\mathrm{a}^{*}$ ), Myoglobin Content, and Their Influence on Muscle Fiber Characteristics and Pork Quality. Korean Journal for Food Science of Animal Resources, $\quad 30$ : 626-633. https://www.doi.org/10.5851/kosfa.2010.30.4.626

Lancha AH, Painelli VS, Saunders B, and Artioli GG (2015). Nutritional strategies to modulate intracellular and extracellular buffering capacity during high-intensity exercise. Sports Medicine, 45: 71-81. DOI: https://www.doi.org/10.1007/s40279-015-0397-5

Ma X, Jiang Z, Zheng C, Hu Y, and Wang L (2015). Nutritional Regulation for Meat Quality and Nutrient Metabolism of Pigs Exposed to High Temperature Environment. Journal of Nutrition and Food Sciences, 5(6): 1-5. DOI: https://www.doi.org/10.4172/2155-9600.1000420

Mudalal SI, and Petracci MI (2019). Effect of sodium chloride replacement with potassium chloride on quality traits of bicarbonate-marinated turkey breast meat. Brazilian Journal of Poultry Science, 21: $1-8 . \quad$ DOI: https://www.dx.doi.org/10.1590/1806-9061-2019-0996

Mushtaq T, Mirza MA, Athar M, Hooge DM, Ahmad T, Ahmad G, Mushtaq MMH, and Noreen U (2007). Dietary sodium and chloride for twenty-nine to forty-two-day-old broiler chickens at constant electrolyte balance under subtropical summer conditions. Journal of Applied Poultry Research, 16: 161-170. DOI: https://www.doi.org/10.1093/japr/16.2.161

Mushtaq MM, Parvin HR, and Kim J (2014). Carcass and body organ characteristics of broilers supplemented with dietary sodium and sodium salts under a phase feeding system. Journal of Animal Science and Technology, 56: 1-7. DOI: https://www.doi.org/10.1186/2055-0391-56-4

Petrolli TG, Junqueira OM, Domingues CHF, Pereira ASC, Santos ET, and Rocha R (2016). Effects of the addition of glucose, sodium bicarbonate, and vitamin $\mathrm{E}$ to the drinking water of pre-slaughter broiler chickens on carcass yield, gastric emptying and meat quality. Brazilian Journal of Poultry Science, 18: 29-34. DOI: https://www.doi.org/10.1590/1516-635x1801029-034

Petracci M, and Cavani C (2012). Muscle growth and poultry meat quality issues. Nutrients, 4: 1-12. DOI: https://www.doi.org/10.3390/nu4010001
Puthpongsiriporn U, Scheideler SE, Sell JL, and Beck MM (2001). Effects of vitamin $\mathrm{E}$ and $\mathrm{C}$ supplementation on performance, in vitro lymphocyte proliferation, and antioxidant status of laying hens during heat stress. Poultry Science, 80: 1190-1200. DOI: https://www.doi.org/10.1093/ps/80.8.1190

Requena B, Zabala M, Padial P, and Feriche B (2005). Sodium bicarbonate and sodium citrate: ergogenic aids? Journal of Strength and Conditioning Research, 19: 213-222. DOI: https://www.doi.org/10.1519/13733.1

Stephens JW, Dikeman ME, Unruh JA, Haub MD, Tokach MD, and Dritz SS (2008). Effects of oral administration of sodium citrate or acetate to pigs on blood parameters, postmortem glycolysis, muscle $\mathrm{pH}$ decline, and quality attributes of pork. Journal of Animal Science, $\quad$ 86: 1669-1677. DOI: https://www.doi.org/10.2527/jas.2007-0797

Tugnoli B, Giovagnoni G, Piva A, and Grilli E (2020). From acidifiers to intestinal health enhancers: How organic acids can improve growth efficiency of pigs. Animals (Basel), 10: 1-18. DOI: https://www.doi.org/10.3390/ani10010134

Woelfel RL, and Sams AR (2001). Marination performance of pale broiler breast meat. Poultry Science, 80: 1519-1522. DOI: https://www.doi.org/10.1093/ps/80.10.1519

Wynveen EJ, Browker AL, Grant AL, Lamkey JM, Fennewalk KJ, Henson L, and Gerrard DE (2001). Pork quality is affected by early postmortem phosphate and bicarbonate injection. Journal of Food Science, 66: 886-891. DOI: https://www.doi.org/10.1111/j.13652621.2001.tb15191.x

Xue X, Liu Z, Li X, Lu J, Wang C, Wang X, Ren W, Sun R, Jia Z, Ji X et al. (2020) The efficacy and safety of citrate mixture vs sodium

bicarbonate on urine alkalization in Chinese primary gout patients with benzbromarone: a prospective, randomized controlled study. Rheumatology, $\quad$ pp. $1-11 . \quad$ DOI: https://www.doi.org/10.1093/rheumatology/keaa668

Yasoob TB, and Tauqir NA (2017). Effect of adding different levels of dietary electrolyte in broiler rations using sodium bicarbonate as a source of electrolyte. Pakistan Journal of Zoology, 49: 2161-2171. DOI: https://www.dx.doi.org/10.17582/journal.pjz/2017.49.6.2161.2171

Zhang L, Yue HY, Zhang HJ, Xu L, Wu SG, Yan HJ, Gong YS, and Qi GH (2009). Transport stress in broilers: I. Blood metabolism, glycolytic potential, and meat quality. Poultry Science, 88: 20332041. DOI: https://www.doi.org/10.3382/ps.2009-00128 